\title{
MENINGKATKAN HASIL BELAJAR LARI SPRINT 60 METER MELALUI PENDEKATAN BERMAIN DENGAN ALAT
}

\author{
Didi Suhaedi \\ SD Negeri Jagara Kabupaten Kuningan \\ Email: suhaedi.didi@gmail.com
}

\begin{abstract}
Abstrak
Pembelajaran Lari sprint 60 meter siswa kelas V SD Negeri Jagara Kecamatan Darma Kabupaten Kuningan, mengalami permasalahan yang timbul dalam pembelajaran dengan hasil pembelajaran siswa yang kurang dari nilai rata-rata dibawah nilai KKM 75. Penelitian ini bertujuan untuk meningkatkan hasil belajar siswa kelas $V$ materi lari sprint 60 meter melalui pendekatan bermain. Penelitian ini menggunakan metode penelitian tindakan kelas yang terdiri atas dua siklus. Subjek penelitian ini adalah siswa kelas V SD Negeri Jagara pada semester II tahun pelajaran 2014/2015 yang berjumlah 50 siswa terdiri atas 29 siswa putra dan 21 siswa putri. Instrumen yang digunakan untuk pengambilan data pada penelitian ini adalah lembar pengamatan, dan tes unjuk kerja siswa. Analisis data yang digunakan dalam penelitian ini adalah analisis deskriptif. Data penelitian menunjukan bahwa pelaksanaan pembelajaran lari sprint 60 meter melalui penerapan pendekatan bermain dengan alat dapat meningkatkan hasil belajar siswa. Kondisi awal persentase siswa yang nilainya mencapai KKM 75 sebesar $40 \%$ atau 20 anak dari jumlah keseluruhan siswa, pada tindakan siklus pertama persentase siswa yang nilainya mencapai KKM mencapai $70 \%$ atau sebanyak 35 siswa kemudian pada siklus kedua persentase ketuntasan belajar mencapai $86 \%$ atau sebanyak 43 siswa.
\end{abstract}

Kata Kunci: Lari, Sprint, Pendekatan, Bermain

\begin{abstract}
Running Learning 60 meter sprint of class V students of SD Negeri Jagara, Darma Subdistrict, Kuningan Regency, experienced problems that arise in learning with student learning outcomes that are less than the average value below the KKM value of 75. This study aims to improve the learning outcomes of class $V$ running material 60 meter sprint through the play approach. This study uses a classroom action research method consisting of two cycles. The subjects of this study were the fifth grade students of Jagara Elementary School in the second semester of the 2014/2015 school year, totaling 50 students consisting of 29 male students and 21 female students. The instruments used for data collection in this study are observation sheets, and student performance tests. The data analysis used in this study is descriptive analysis. The research data shows that the implementation of 60 meter sprint learning through the application of a play approach with tools can improve student learning outcomes. The initial condition of the percentage of students whose grades reach KKM 75 is $40 \%$ or 20 children of the total number of students, in the first cycle the percentage of students reaching KKM reaches $70 \%$ or 35 students then in the second cycle the percentage of learning completeness reaches $86 \%$ or 43 students.
\end{abstract}

Keywords: Run, Sprint, Approach, Play 


\section{PENDAHULUAN}

Pendidikan jasmani merupakan suatu aktivitas jasmani yang didesain untuk meningkatkan kesegaran jasmani yang disalurkan melalui suatu proses pembelajaran, dengan menggembangkan keterampilan motorik, pengetahuan dan perilaku hidup sehat dan aktif, sikap sportif, dan kecerdasan emosi. Tujuan yang ingin dicapai ialah bermacam-macam mencakup pengembangan individu secara menyeluruh, yaitu aspek jasmani, aspek mental, emosi, social, dan spiritual. Dalam hal ini Mahendra (2003:4) menjelaskan bahwa: "Pendidikan jasmani pada hakekatnya adalah proses pendidikan yang memanfaatkan aktivitas fisik untuk menghasilkan perubahan holistik dalam kualitas individu, baik dalam hal fisik, mental serta emosional".

Melalui pendidikan jasmani diharapkan siswa dapat memperoleh berbagai pengalaman untuk mengungkapkan kesan pribadi yang menyenangkan, kreatif, inovatif, terampil, meningkatkan serta pemahaman terhadap gerak manusia. Sesuai dengan karakteristiknya, anak usia 6-13 tahun cenderung masih suka bermain. Untuk itu guru harus dapat mengembangkan pembelajaran yang efektif, di samping harus memahami dan memperhatikan karakteristik dan kebutuhan siswa. Pada usia tersebut seluruh aspek perkembangan baik kognitif, psikomotor dan afektif mengalami perubahan.

Pelaksanaan pembelajaran pendidikan jasmani didalamnya diajarkan beberapa macam cabang olahraga yang terangkum kurikulum pendidikan jasmani, salah satu cabang olahraga yang diajarkan dalam pendidikan jasmani yaitu atletik. Atletik sendiri terdiri menjadi beberapa nomor diantaranya, jalan, lari lempar dan lompat. Pengajaran dan pengembangan olahraga atletik khusunya lari dimulai sejak usia dini yaitu periode umur anak kurang 6 tahun, sampai dengan 14 tahun dimana hakekatnya merupakan bagian dari kebijakan nasional. Lari jarak pendek adalah semua nomor lari yang dilakukan dengan kecepatan penuh (sprint) atau kecepatan maksimal, sepanjang jarak yang harus ditempuh. Sampai dengan jarak 400 meter, masih digolongkan dalam lari jarak pendek. (Adisasmita, 1992:35). Jadi, dalam nomor lari ini yang diutamakan adalah kecepatan yang maksimal dari awal lari (start) sampai akhir lari atau finish (Munasifah, 2008: 13). Kelangsungan gerak sprint dapat dibedakan menjadi 3 (tiga) bagian yaitu start, gerakan sprint, dan gerakan finish (Munasifah, 2008: 14).

Nomor 60 meter merupakan salah satu nomor lari pengembangan jarak pendek, yang diajarkan di sekolah dasar berdasarkan usia anak didik tersebut. Nomor 60 meter artinya pelari harus melakukan lari secepat-cepatnya dengan 
menggerakkan seluruh kemampuan yang dimiliki mulai dari awal hingga akhir sepanjang 60 meter. Kecepatan lari khususnya lari 60 meter dapat dicapai secara optimal apabila dilakukan suatu pengajaran yang baik, terprogram terpadu serta sistematis.

Berdasarkan hasil pengamatan, observasi, dan penilaian secara langsung terhadap siswa kelas V SD Negeri Jagara Kecamatan Darma dalam pembelajaran Lari sprint 60 meter siswa mengalami permasalahan yang timbul dalam pembelajaran dengan hasil pembelajaran siswa yang kurang dari nilai rata-rata dibawah nilai KKM 75. Data menunjukan bahwa persentase siswa yang nilainya mencapai KKM 75 sebesar $40 \%$ atau 20 anak dari jumlah keseluruhan siswa. Materi Dengan kondisi demikian perlu kiranya ada suatu pendekatan pembelajaran yang efektif guna memperbaiki dan meningkatkan hasil belajar pada lari sprint tersebut.

Untuk mengatasi keadaan tersebut dilakukan perbaikan pembelajaran dengan penggunaan pendekatan yang berbeda dari sebelumnya. Salah satu pendekatan yang dapat diterapkan adalah pembelajaran lari cepat menggunakan pemdekatan bermain. Bermain sebenarnya merupakan dorongan dari dalam anak, atau disebut merupakan naluri. Semua naluri atau dorongan dari dalam ini harus diusahakan untuk disalurkan secara baik dan terkontrol. Oleh karena itu bermain bagi anak merupakan kebutuhan hidupnya, seperti kebutuhankebutuhan lainnya seperti makan, minum, tidur dan lain-lainnya. Smith seorang psikolog mengatakan bahwa bermain adalah dorongan langsung dari dalam diri setiap individu (dalam Soemitro, 1992: 2).

Bermain merupakan kegiatan yang dilakukan anak secara berulang-ulang demi kesenangan tanpa adanya tujuan dan sasaran yang hendak dicapai (Harsono, 1988:103). Permainan sebagai suatu media yang meningkatkan perkembangan kognitif anak-anak. Permainan memungkinkan anak mempraktikan kompetensi dan keterampilan yang diperlukan dengan cara yang santai dan menyenangkan. Bermain dalam situasi berlomba atau bertanding dengan pengorganisasian yang sederhana. Misalnya: berlomba dalam beberapa macam gerakan seperti berlari, merayap, melompat, menggiring bola, adu lempar tangkap dan sebagainya. Melakukan pertandingan cabang olahraga yang peraturannya disederhanakan, misalnya pertandingan adu lari memindahkan bola. Dengan pengarahan dan pengelolaan aktivitas yang baik dari guru, aktivitas ini akan berdampak kepada peningkatan kepercayaan diri anak dan kebanggaan dirinya, (Soegiyanto, 2001:3738).

Pendidikan moderen berpendapat bahwa bermain merupakan alat pendidikan. Pendidikan yang baik akan mengetengahkan bermain sebagai alat pendidikan. Pestalozzi seorang paedagog 
yang terkenal dari Swiss pada abad ke 18, menekankan perlunya bermain karena mempunyai nilai-nilai untuk mengembangkan harmoni antara jiwa dan raga. John Locke seorang filosof bangsa inggris pada abad ke 17, ia meyakini bahwa bermain dapat membantu dalam usaha mencapai tujuan pendidikan. Montessori sangat menghargai nilai-nilai yang terdapat didalam permainan pada masa kanakkanak. Pada sekolah mereka baik Frobel maupun Montesori, menerapkan suatu pemikiran: "anak-anak belajar sesuatu dalam bermain." Jadi mereka menggunakan bermain sebagai alat untuk mendidik (Soemitro, 1992: 3).

Seperti dimaklumi bersama, pada usia sekolah dasar, bermain merupakan salah satu kebutuhan yang tidak dapat digantikan oleh kegiatan apapun. Oleh karena itu. Dalam upaya meningkatkan hasil belajar lari sprint 60 meter ini penulis menerapkan pendekatan bermain. Diharapkan melalui teknik ini siswa mengalami suasana kompetitif. Adanya sifat kompetitif ini membawa siswa merasa tertantang untuk memperoleh kemajuan dan berusaha mengatasi setiap problem yang ia temui dalam berlari. Terciptanya situasi yang kompetitif ini dapat meningkatkan semangat dan motivasi siswa untuk melakukan aktivitas gerak dengan sebaikbaiknya sehingga dapat berimplikasi terhadap peningkatan hasil belajar siswa khususnya materi lari sprint.

\section{METODE}

Metode yang digunakan dalam penelitian ini adalah metode kualitatif dengan model penelitian tindakan kelas. Dalam penelitian tindakan kelas, guru dapat meneliti terhadap praktek pembelajaran yang ia lakukan di kelas dengan dibantu oleh kolaborator, melalui tindakan-tindakan yang direncanakan, dilaksanakan dan dievaluasi.

Penelitian tindakan kelas dalam pendidikan jasmani adalah suatu bentuk kajian yang bersifat reflektif dan dilakukan untuk meningkatkan kemampuan rasional dari tindakan-tindakan guru dalam memperdalam tugas, memperdalam pemahaman terhadap tindakan-tindakan yang dilakukannya, serta memperbaiki kondisi dimana praktek pembelajaran Penjas tersebut dilakukan, dimulai dari adanya perencanaan, pelaksanaan, observasi, dan refleksi untuk setiap siklusnya (Agus, 2010:32). 


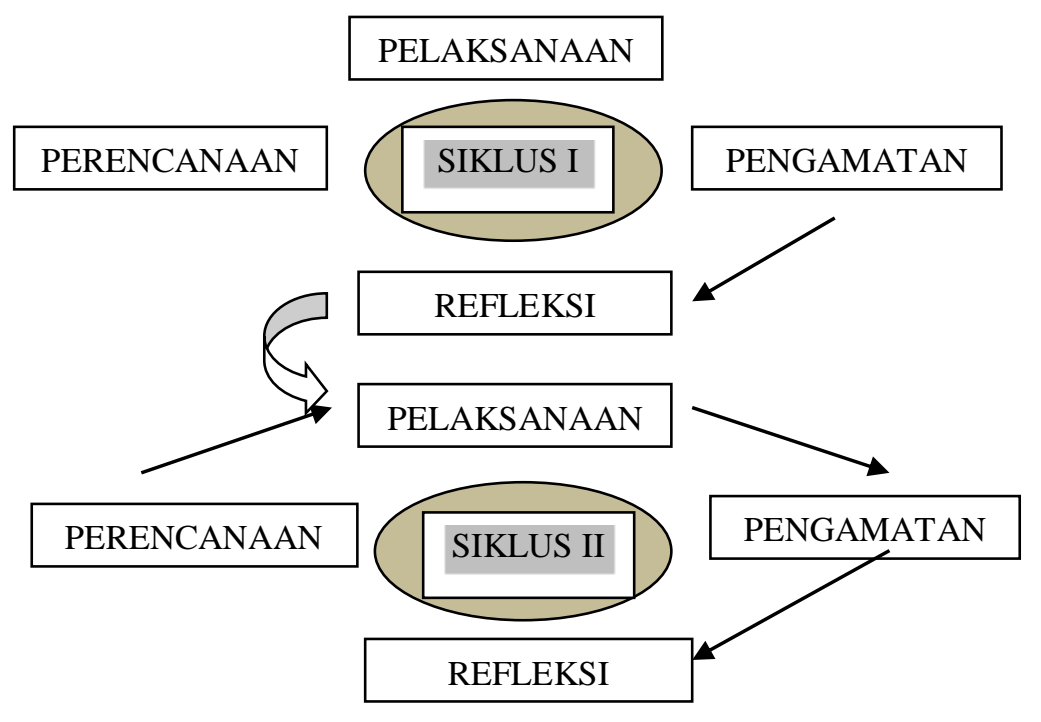

Gambar 1. Alur Siklus Penelitian Tindakan Kelas Sumber : Arikunto, 2008:16

Subjek penelitian adalah siswa kelas V Sekolah Dasar Negeri Jagara Kecamatan Darma Kabupaten Kuningan semester I tahun Pelajaran 2014/2015 yang berjumlah 50 siswa dengan rincian 29 siswa laki-laki dan 21 siswa perempuan. Peneliti memilih Negeri Jagara karena peneliti merupakan guru Penjasorkes di SD ini. Teknik pengumpulan data dalam penelitian tindakan kelas ini terdiri dari teknik tes dan teknik nontes. Teknik tes yang dipergunakan untuk mendapatkan data hasil pembelajaran siswa yaitu lari sprint 60 meter yang dilakukan siswa. Teknik nontes dipergunakan untuk mengumpulkan data tentang aktivitas siswa dan guru selama kegiatan pembelajaran. Teknik nontes yang digunakan dalam penelitian ini yaitu observasi, dokumentasi, dan check list.

Instrumen penelitian adalah alat atau fasilitas yang digunakan oleh peneliti dalam mengumpulkan data agar pekerjaannya lebih mudah dan hasilnya akan lebih baik, dalam arti lebih cermat, lengkap, dan sistematis sehingga mudah diolah (Arikunto, 2006:149). Instrumen pengumpulan data yang digunakan dalam penelitian ini adalah aspek kognitif, afektif, dan psikomotor.

\section{HASIL PENELITIAN}

Hasil penelitian tindakan kelas pada siswa kelas V SD Negeri Jagara dapat dipaparkan pembahasan hasil penelitian sebagai berikut.

\section{Perbandingan Hasil Belajar \\ Prasiklus ke Siklus I}

Perbandingan peningkatan nilai ketuntasan belajar lari sprint 60 meter siswa kelas V SD Negeri Jagara dari kondisi awal ke siklus I disajikan dalam tabel 9. 
Tabel 1

Perbandingan Peningkatan Hasil Belajar dari Prasiklus ke Siklus I

\begin{tabular}{|c|c|c|}
\hline $\begin{array}{c}\text { Nilai Terendah } \\
\text { Pra Siklus }\end{array}$ & $\begin{array}{c}\text { Nilai Terendah pada } \\
\text { siklus I }\end{array}$ & $\begin{array}{c}\text { Peningkatan Kualitas } \\
\text { Belajar Siklus I }\end{array}$ \\
\hline 68 & 69 & 1,00 \\
\hline Nilai Tertinggi Pra siklus & $\begin{array}{c}\text { Nilai Tertinggi pada } \\
\text { siklus I }\end{array}$ & $\begin{array}{c}\text { Peningkatan Kualitas } \\
\text { Belajar lari sprint } 60 \\
\text { meter Siklus I }\end{array}$ \\
\hline 81 & 82 & 1,00 \\
\hline
\end{tabular}

Berdasarkan tabel 9, terdapat peningkatan hasil belajar yang signifikan atara prasiklus dengan Siklus I. Lebih jelasnya berikut ini disajikan diagram peningkatan nilai rata-rata hasil belajar lari sprint 60 meter siswa kelas V SD Negeri Jagara dari kondisi awal ke siklus 1 sebagai berikut.

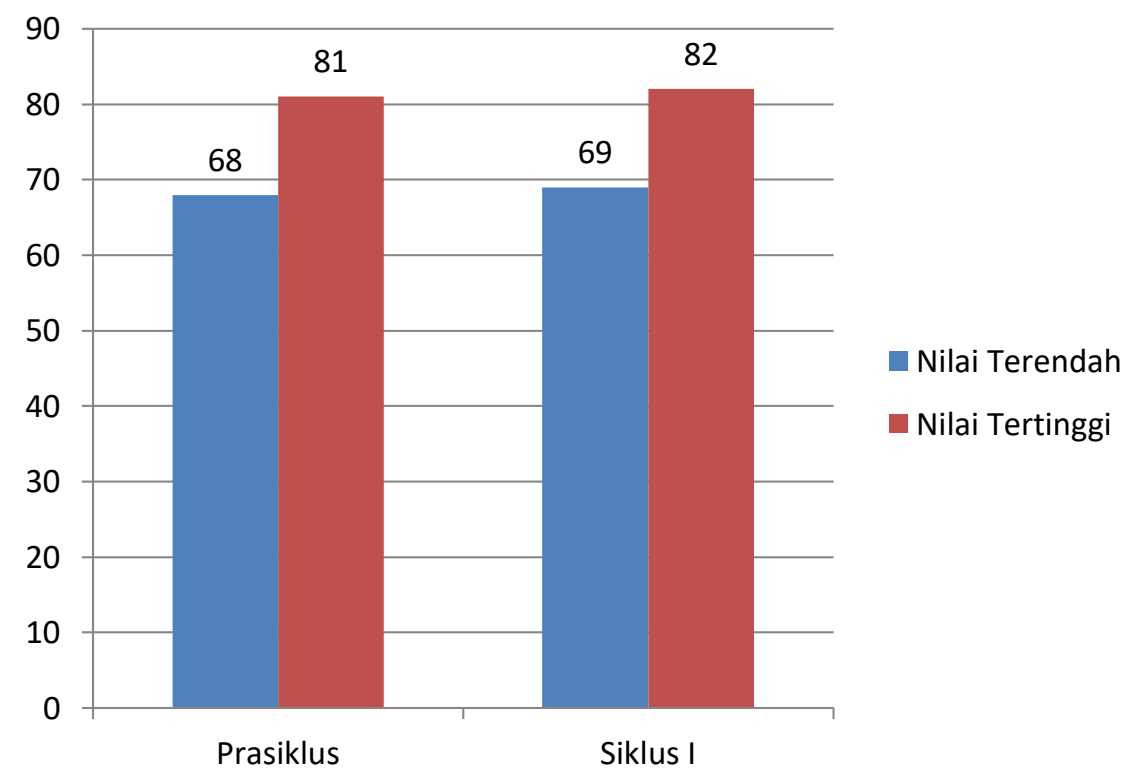

Diagram 1

Peningkatan Hasil Belajar Prasiklus ke Siklus I

Dari diagram di atas jelas terlihat perbandingan jumlah siswa yang memperoleh nilai ketuntasan diatas KKM meningkat dari pra siklus sejumlah 35 siswa sehingga menunjukan bahwa nilai hasil belajar lari sprint 60 meter siswa kelas V Sekolah Dasar Negeri Jagara Kecamatan Darma Kabupaten Kuningan mengalami peningkatan yang cukup signifikan. Hal ini memperlihatkan bahwa nilai hasil belajar lari sprint 60 meter dari kondisi awal ke siklus I mengalami peningkatan rata-rata sebesar 3,00.

\section{Perbandingan Hasil Belajar dari Siklus I ke Siklus II}


Perbandingan peningkatan nilai

hasil belajar lari sprint 60 meter siswa kelas
V SD Negeri Jagara dari siklus I ke siklus II disajikan dalam bentuk tabel berikut.

Tabel 2

Perbandingan Peningkatan Hasil Belajar dari Siklus I ke Siklus II

\begin{tabular}{|c|c|c|}
\hline Nilai Terendah Siklus I & Nilai Terendah siklus II & $\begin{array}{c}\text { Peningkatan Kualitas } \\
\text { Siklus II }\end{array}$ \\
\hline 69 & 70 & 1,00 \\
\hline Nilai Tertinggi siklus I & Nilai Tertinggi siklus II & $\begin{array}{c}\text { Peningkatan Kualitas } \\
\text { Siklus II }\end{array}$ \\
\hline 82 & 85 & 3,00 \\
\hline
\end{tabular}

Berikut ini disajikan diagram Negeri Jagara dari kondisi awal ke siklus 2 peningkatan nilai ketuntasan hasil belajar sebagai berikut. lari sprint 60 meter siswa kelas V SD

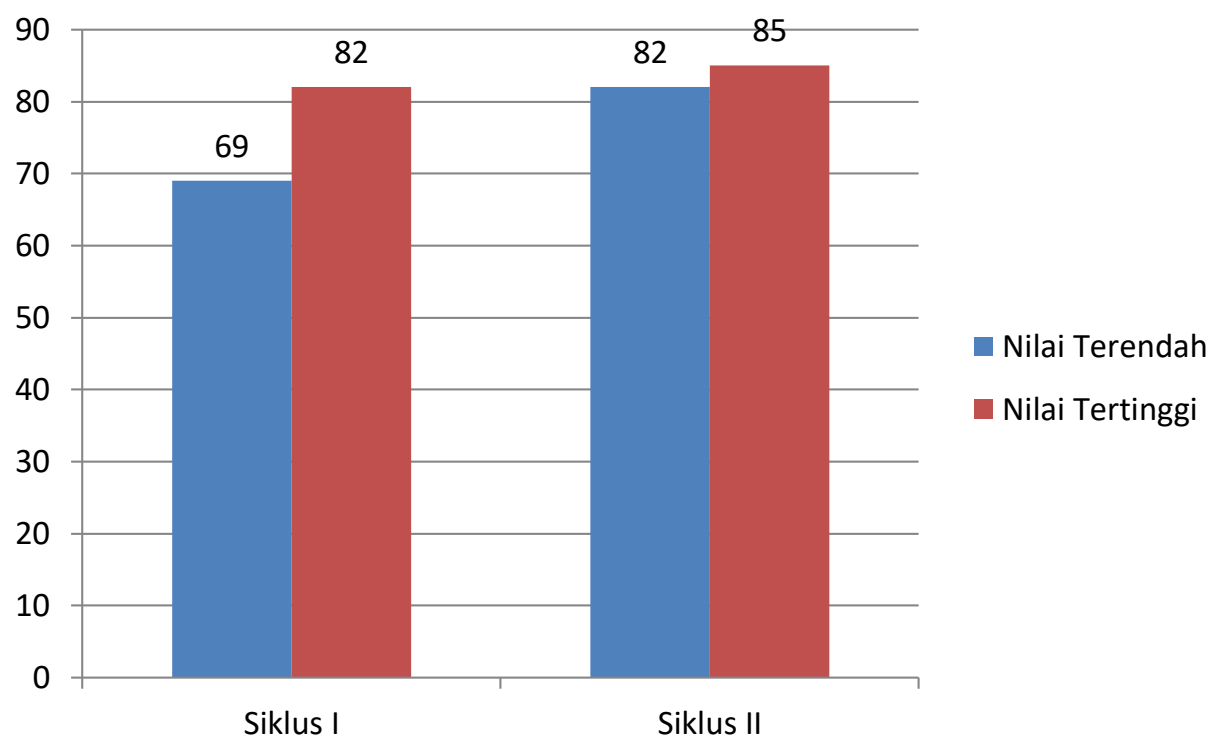

Diagram 2

Peningkatan Hasil Belajar dari Siklus I ke Siklus II

Diagram di atas menunjukkan bahwa nilai ketuntasan belajar lari sprint 60 meter siswa kelas V SD Negeri Jagara mengalami peningkatan yang sangat baik. Hal ini terlihat dari nilai rata-rata hasil belajar lari sprint 60 meter mengalami peningkatan dari siklus I ke siklus II sebesar 2,00.
3. Perbandingan Hasil Belajar dari Prasiklus ke Siklus II

Perbandingan peningkatan nilai hasil lari sprint 60 meter siswa kelas V SD Negeri Jagara dari kondisi awal ke siklus II disajikan dalam bentuk tabel berikut. 
Tabel 3

Perbandingan Peningkatan Hasil Belajar dari Prasiklus ke Siklus II

\begin{tabular}{|c|c|c|}
\hline Nilai Terendah Prasiklus & Nilai Terendah siklus II & $\begin{array}{c}\text { Peningkatan Hasil } \\
\text { Belajar Siklus II }\end{array}$ \\
\hline 68 & 70 & 2,00 \\
\hline Nilai Tertinggi Prasiklus & Nilai Tertinggi siklus II & $\begin{array}{c}\text { Peningkatan Hasil } \\
\text { Belajar Siklus II }\end{array}$ \\
\hline 81 & 85 & 4,00 \\
\hline
\end{tabular}

Lebih jelasnya berikut ini disajikan grafik peningkatan nilai ketuntasan hasil belajar lari sprint 60 meter siswa kelas $\mathrm{V}$
SD Negeri Jagara dari kondisi awal ke Siklus II sebagai berikut.

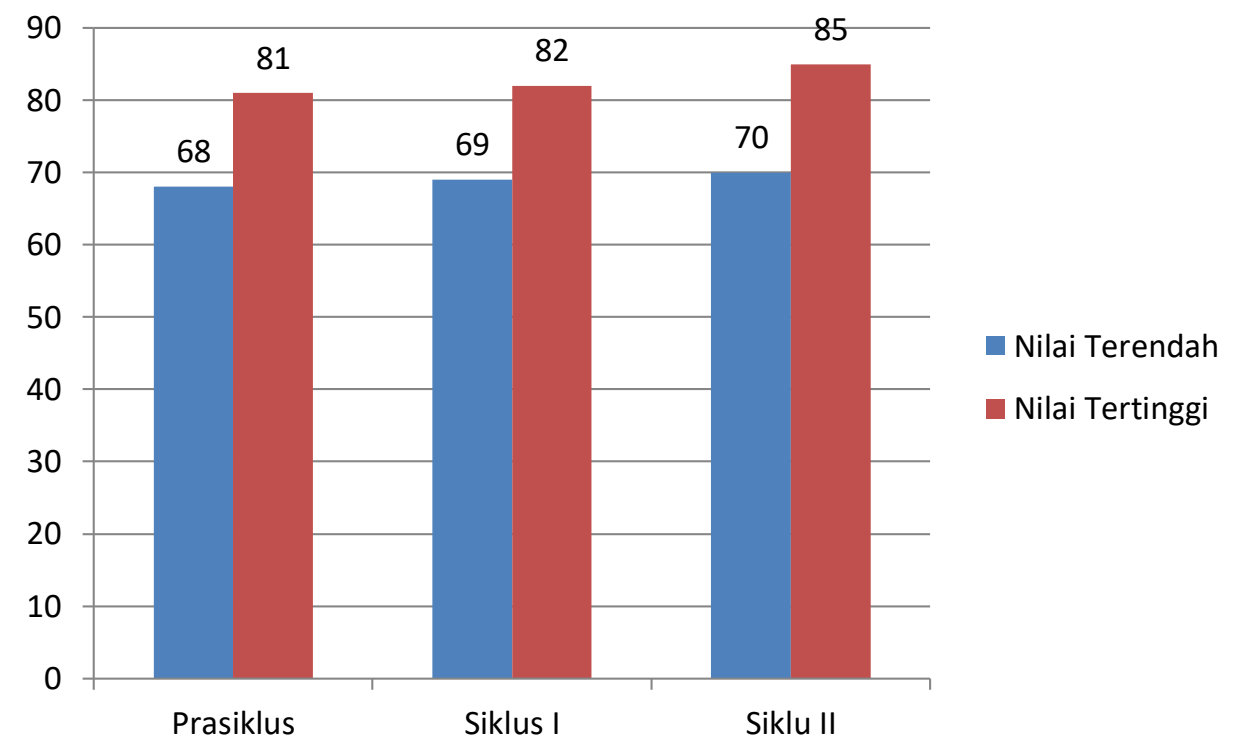

Diagram 3

Peningkatan Hasil Belajar dari Prasiklus sampai ke Siklus II

Dari diagram di atas sangat jelas terlihat perbandingan jumlah siswa yang memperoleh nilai diatas KKM sebelum diadakan tindakan dengan setelah diadakan tindakan, sehingga nilai hasil belajar lari sprint 60 meter siswa kelas V SD Negeri
Jagara mengalami peningkatan yang sangat baik. Sangat jelas terlihat bahwa nilai hasil belajar lari sprint 60 meter dari kondisi awal ke siklus II mengalami peningkatan rata-rata sebesar 5,00. 


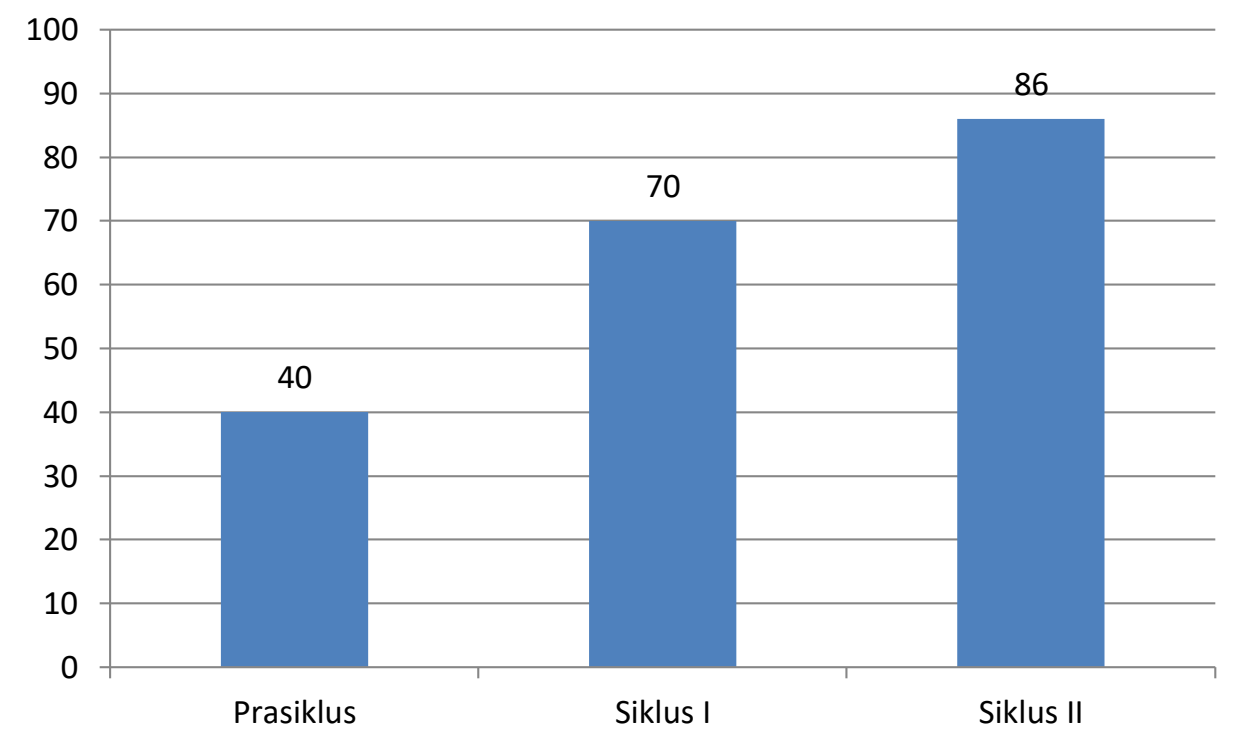

Diagram 4

Peningkatan Hasil Belajar Siswa Tiap Siklus

Berdasarkan hasil penelitian yang telah dilakukan pada siklus I jumlah siswa yang mendapatkan nilai diatas KKM berangsur-angsur naik, sehingga pada siklus II jumlah tersebut sudah melebihi target. Kemajuan ini terjadi karena siswa merasa senang dengan penerapan permainan hijauhitam, lebih bersemangat dan aktif mengikuti proses pembelajaran serta peneliti selalu memberikan dorongan dan motivasi belajar. Hal ini sejalan dengan adanya perubahan perilaku peserta didik yang menunjukan keaktifan dalam mengikuti proses pembelajaran dengan baik (Moh. Surya, 1997).

Penerapan pembelajaran melalui permainan yang bersifat tantangan berbentuk perlombaan akan berdampak dalam menumbuhkan minat, meningkatkan kepercayaan diri siswa, meningkatkan kemampuan motorik anak (Sugiyanto dan
Sujarwo, 1992:127-128). Sehingga dapat disimpulkan melalui penerapan permainan mengumpulkan balok pembelajaran materi lari sprint 60 meter dapat meningkatkan hasil belajar siswa, meningkatkan kualitas pembelajaran, meningkatkan ketuntasan hasil belajar serta menciptakan pembelajaran yang aktif, inovatif, kreatif, efektif, dan menyenangkan sehingga tujuan pembelajaran bisa tercapai.

Data peningkatan nilai hasil belajar lari sprint 60 meter pada siswa kelas V SD Negeri Jagara dari siklus I ke siklus II menunjukan peningkatan rata-rata sebesar 2,00 . Sedangkan nilai rata-rata hasil belajar lari sprint 60 meter mengalami peningkatan sebesar 78,00. Hal ini menunjukan bahwa, penerapan pendekatan bermain dengan alat untuk meningkatkan kemampuan lari sprint 60 meter siswa pada siklus II telah berhasil. 
Kemajuan hasil belajar ini ditandai dengan adanya peningkatan ketuntasan belajar 8 siswa yang memperoleh nilai diatas KKM dari kondisi siklus I ke siklus II. Sehingga jumlah keseluruhan ketuntasan belajar sampai akhir siklus II sejumlah 43 siswa (86\%). Kualitas gerak serta jawaban siswa cukup baik karena dari 50 siswa yang bisa menjawab dengan benar sejumlah 43 siswa sedangkan 7 siswa lainnya jawabannya kurang sempurna. Kemampuan menjawab soal dapat dikatakan semakin baik karena jawaban tersebut dikomentari dengan kata-kata logis, singkat, kalimat bagus dan benar.

Selama pelaksanaan siklus II terdapat kelebihan yang dapat digunakan sebagai tolok ukur keberhasilan, adapun kelebihannya antara lain: 1) sebagian besar siswa telah mampu melakukan lari sprint 60 meter mulai dari awalan start, saat melakukan awalan lari dan sikap badan saat melewati garis finish 2) Melalui pembelajaran dengan penerapan pembelajaran hijau hitam pada materi lari sprint 60 meter siswa lebih tertarik, lebih antusias, senang, dan aktif dalam mengikuti pembelajaran. 3) kualitas jawaban yang diberikan lebih baik dengan menggunakan tata bahasa yang bagus, singkat dan benar.

Hasil observasi atau pengamatan serta refleksi selama pelaksanaan siklus II dapat diidentifikasikan telah berhasil atau tuntas sesuai dengan persentase target pencapaian yaitu $80 \%$ sehingga penerapan permainan mengumpulkan balok pada materi lari sprint 60 meter telah berhasil sesuai dengan tujuan peneliti.

\section{SIMPULAN}

Berdasarkan hasil penelitian dan pembahasan sebagaimana telah dipaparkan sebelumnya, maka dapat diambil simpulan sebagai berikut.

1. Melalui penerapan pendekatan bermain dengan alat dapat meningkatkan hasil belajar Lari sprint 60 meter pada siswa kelas V SD Negeri Jagara Kecamatan Darma Kabupaten Kuningan Tahun Pelajaran 2014/2015 ditandai dengan meningkatnya ketuntasan nilai hasil belajar. Hal ini sejalan dengan hasil data temuan yang diperoleh peneliti pada kondisi awal pra siklus ke siklus I sampai akhir siklus II.

2. Persentase nilai ketuntasan hasil belajar siswa kelas V SD Negeri Jagara pada kondisi awal pra siklus sebesar $40 \%$ atau sejumlah 20 siswa yang mencapai ketuntasan belajar dari 50 siswa keseluruhan, kemudian pada siklus I terjadi peningkatan sebesar $70 \%$ atau sejumlah 35 siswa dan pada akhir siklus II meningkat sebesar $86 \%$ atau sejumlah 43 siswa yang mencapai ketuntasan belajar, sehingga peningkatan dari kondisi awal pra siklus hingga akhir siklus II sebesar $46 \%$. 
3. Penerapan pembelajaran melalui permainan yang bersifat tantangan berbentuk perlombaan akan berdampak dalam menumbuhkan minat, meningkatkan kepercayaan diri siswa, meningkatkan kemampuan motorik anak.

\section{DAFTAR PUSTAKA}

Adisasmita, Yusuf. 1992. Olahraga Pilihan Atletik. Depdikbud. Jakarta

Anni, Catharina Tri. 2008. Psikologi Belajar. UNNES: UPT MKK UNNES

Arikunto, Suharsimi. 2006. Prosedur Penelitian Suatu Pendekatan Praktik. Jakarta: Rineka Cipta.

Arikunto, Suharsimi. 2008. Dasar-dasar Evaluasi Pendidikan. Jakarta : Bumi Aksara

Arikunto, Suharsimi. 2008. Prosedur Penelitian Suatu Pendekatan Praktik.. Jakarta : Rineka Cipta.

Arikunto, Suharsimi. 2010. Prosedur Penelitian Suatu Pendekatan Praktik. Jakarta: PT Rineka Cipta.

Ateng, Abdul Kadir. 1992. Azas dan Landasan Pendidikan Jasmani. Jakarta Depdikbud Dirjen Dikti

Dikpora Jawa Barat. 2013. Petunjuk Pelaksanaan Popda Tingkat I Jawa Barat. Bandung

Djumijar. 2004. Atletik http://www.google.com/search?q=pe $\underline{\text { ngertian+lari+sprint }} \underline{\&}$ client=firefox diakses pada 12 mei 2013
Harsono, 1988. Coacing dan Aspek-aspek Psikologi dalam Coacing, Jakarta : Tambak Kusumo.

Mahendra, Agus. (2003). Falsafah Pendidikan Jasmani. Jakarta: Depdiknas

Mahendra, Agus. 2008. Permainan Anak dan Aktivitas Ritmik. Jakarta: Universitas Terbuka

Munasifah. 2008. Atletik Cabang Lompat, Aneka Ilmu.

Nadisah. 1992. Pengembangan kurikulum pendidikan jasmani dan kesehatan. Jakarta Depdikbud Dirjen Dikti

Sanjaya, Wina. 2011. Strategi Pembelajaran Berorientasi Standar Proses Pendidikan. Jakarta: Kencana Prenada Media

Soegiyanto, Soedjarwo. 2001. Permainan Kecil. Jakarta: Depdikbud Dirjen Dikti

Soemitro, Yosaphat. 1992. Dasar-dasar Atletik. Universitas Terbuka. Depdikbud.

Syah, Muhibbin. 2008. Psikologi Belajar. Jakarta : PT Raja Grafindo Persada. Syaifudin, Aip. 2007. Penyusunan Skala Psikologi. Yogyakarta: Pustaka Pelajar.

Unitas dan Dintiman. 1979. Atletik. Jakarta: Departemen Pendidikan Nasional. Direktorat Jendral Pendidikan Dasar dan Menengah. 
Waluyo. 2011. Teknologi Pendidikan dalam Penjas.Universitas Sebelas Maret Surakarta
Yoyo, B. Yusuf, U., dan Suherman, A. 2000. Atletik. Depdikbud. Dirjendikdasmen. 